\title{
FRONTIERISATION DAN DEFRONTIERISATION Sebagai Kerangka Untuk Studi Marjinalitas: Kasus Dataran Lindu Di Sulawesi Tengah
}

\author{
Greg Acciaioli \\ Muhammad Nasrum
}

\begin{abstract}
Abstrak: Bersandar kepada naskah lama dan mutakhir yang menggunakan konsep frontier, tulisan ini menyajikan studi kasus proses frontierisation dan defrontierisation di Dataran Lindu, Sulawesi Tengah. Sesudah penjelasan difokuskan pada proses, tulisan ini menggambarkan pula sejarah Dataran Lindu melalui empat dimensi frontierisation - yaitu kendali, ekstraksi, pemukiman, dan konservasi - dari zaman prakolonial sampai era pascareformasi. Studi kasus tersebut digunakan untuk memikirkan kembali gagasan seperti pembalikan status frontier dengan mengurangi perhatian pada indikator demografis dan ekonomis dan lebih memfokuskan pada faktor lain, seperti agensi dari masyakarat lokal yang didominasi/dipinggirkan dalam usaha membalikkan relasi kuasa. Hal itu kemudian menjadi kriteria utama dalam pembalikan status frontier (defrontierisation). Pembalikan status frontier ini seperti terlihat pada perubahan posisi To Lindu sebagai orang asli di wilayah Sulawesi Tengah. Mereka telah mengalami banyak peristiwa; mulai dari keadaan dipinggirkan di masa kolonial, lalu didominasi oleh migran Bugis yang memperkuat usaha kewiraswastaannya dengan menggunakan alasan pembangunan dan aliansi dengan instansi pemerintah pada era pascakolonial, sampai pada peristiwa penarikan kembali penguasaan atas wilayahnya oleh masyarakat To Lindu melalui aliansi dengan gerakan masyarakat adat dan organisasi konservasi di era reformasi dan pascareformasi.
\end{abstract}

Kata kunci: frontier, frontierisation, defrontierisation, marjinalitas, masyarakat pinggiran, Lindu Bugis, Sulawesi Tengah.

Dicetak dulu sebagai Greg Acciaioli dan Muhammad Nasrum. "Frontierisation dan Defrontierisation Sebagai Kerangka Untuk Studi Marjinalitas: Kasus Dataran Lindu Di Sulawesi Tengah” Jurnal Masyarakat \& Budaya, Vol. 22 No. 1 (2020): 57-74.

Pendahuluan: Dari Frontier ke Frontierisation dan Defrontierisation

...Selain memerlukan telaah yang bersifat makro tentang konstitusi dan berbagai perundangan yang ada, satu hal yang sangat penting dilakukan adalah melakukan analisis tentang proses-proses sosial, politik, ekonomi maupun kebudayaan yang dianggap telah mengakibatkan terjadinya peminggiran sebagian warga bangsa, seperti dialami oleh komunitas-komunitas adat, penganut agama minoritas, kaum difabel, LGBT, buruh migran dan lainnya. Analisis sistimatik diperlukan selain untuk memahami proses yang terjadi, juga untuk mengenali dinamika internal yang terjadi di dalam masyarakat- masyarakat pinggiran 
itu sendiri. Analisis perlu menekankan pentingnya melihat dimensi relasi-kuasa (power relations) antara institusi-institusi, para aktor dan agensi- agensi yang terlibat dalam proses sosial, politik, ekonomi dan kebudayaan yag terjadi

(Tirtosudarmo, 1917.: 2).

Kalimat di atas merupakan rumusan ketiga dari lokakarya dengan tema inisiatif Tim Unggulan Ketahanan Sosial (TUKS) - LIPI, bekerjasama dengan Pusat Studi Laman Batas dan Pusat Studi Kebumian - Universitas Brawijaya dan Center for Religious and Cultural Studies (CRCS) - Universitas Gajah Mada pada tanggal 9-10 November 2016 di Kampus Universitas Brawijaya, Malang. Tulisan ini dimaksudkan sebagai sumbangan untuk mendalami satu bentuk peminggiran dan usaha untuk mengatasi peminggiran yang merupakan ciri sejarah dari sebagian masyarakat pinggiran, yaitu yang tinggal di daerah pinggiran dalam arti geografis, seperti komunitas adat. Proses itu penulis namakan frontierisation dan pembalikannya penulis sebut dengan istilah defrontierisation. Jelas, nama kedua proses timbal-balik itu berasal dari kata frontier, ${ }^{1}$ satu gagasan yang akhir-akhir ini mulai digunakan lagi dan diperluas sebagai sebuah kerangka untuk mempelajari interaksi antara masyarakat yang wilayahnya diduduki dengan pihak yang mendudukinya dan dengan lingkungan dalam suatu konteks global.

Dalam pidato resminya pada tahun 1893 yang berjudul 'The Significance of the Frontier in American History' (1994), sejarawan Frederick Jackson Turner untuk pertama kalinya memunculkan suatu debat yang bertahan selama beberapa dasawarsa menyangkut signifikansi dari frontier dalam mengokohkan

\footnotetext{
${ }^{1}$ Meskipun menurut Stevens \& Schmidgall- Tellings
}

(2004: 282), istilah frontir sudah masuk Bahasa ciri khas Amerika dalam perdagangan bebas dan politik individualisme (laissez faire) yang menopangnya. Karya Owen Lattimore memperluas kegunaan gagasan tersebut dengan lebih meningkatkan proses dialektika antara ekspansi dan penarikan kembali. Proyek intelektual yang dilakukan seumur hidup oleh Lattimore adalah mengembangkan suatu model "ilmiah" bagaimana masyarakat secara umum terbentuk, berkembang, tumbuh, merosot, dan bermutasi dalam konteks berinteraksi dengan masyarakat lain sepanjang frontier (Rowe, 2007: 259). Tulisannya memfokuskan pada perbatasan kekaisaran Cina, yang dia visualkan sebagai wilayah-wilayah perebutan - suatu pasang surut masyarakat Cina dan tetangganya (masyarakat Manchuria, Mongolia, dan Tibet) yang interaksinya dipandu oleh parameterparameter ekologi terkait dengan tingkatan teknologi relatif dari pihak-pihak yang melakukan interaksi.

Oleh karena itu, frontier lebih tepat jika disebut sebagai zona sosial yang berfluktuasi, daripada didefinisikan melalui perbedaan khas secara geografis yang interaksi antara masyarakat dibedakan secara sosial dan ekonomi, baik pihak yang menduduki maupun pihak yang diduduki. Pendefinisian frontier sebagai zona sosial berfluktuasi tersebut tentu memiliki beragam konsekuensi - baik amalgamasi, pengusiran, maupun perpaduan keduanya, tergantung pada perbedaanperbedaan relatif dari pihak yang menduduki dan pihak yang diduduki dalam kompleksitas sosial, skala sosial, serta "tekad sosial dan kekuatan institusional” (Lattimore, 1968: 374). Frontier menciptakan formasi sosial baru, seperti tribalisme dan feodalisme, yang dimunculkan untuk mengupayakan kehidupan pihak yang menduduki dan pihak yang "frontier", dengan huruf miring. 
diduduki secara berdampingan (Lattimore, 1968: 377-378).

Berbeda dengan pandangan awal para sejarawan dan ahli geografi, para antropolog cenderung lebih berkonsentrasi pada agensi golongan marjinal yang diduduki - "sisi lain dari frontier" (Bohannan, 1967: xii) - serta pengaruh mereka pada pihak yang menduduki (Hallowell, 1967). Di samping mempengaruhi pembalikan arah teoretis tersebut, para antropolog secara aktif telah menggunakan frontier sebagai sebuah kerangka pelacakan etnografis situasi-situasi tertentu yang menunjukkan kompleksitas multietnis (misalnya, Cole dan Wolf, 1974; Little, 2001).

Pendapat yang lebih mutakhir muncul dari Anna Tsing yang menekankan dampak transformasi wilayah Meratus di Kalimantan Selatan menjadi sebuah frontier yang ditandai dengan koeksistensi yang saling berlawanan dari pemaksaan ekonomi yang terorganisasi, hamparan luas perkebunan monokultur akasia, kelapa sawit, dan tanaman lainnya, serta keliaran para individu yang masuk ke area untuk melakukan "perusakan" melalui penebangan, pertambangan, dan usaha lainnya. Tsing sendiri mencatat relevansi konseptualisasi Turner mengenai frontier sebagai tempat pertemuan antara kebiadaban dan kebudayaan. Lebih lanjut, tokoh pemerintah Indonesia sendiri telah mencatat persamaannya dengan frontier Amerika: 'Kalimantan pada saat ini adalah bagian dari Wild West (Barat yang Liar).... seperti bagian dari Amerika di abad kesembilan belas....' (Menteri Lingkungan Hidup Indonesia dikutip dalam Tsing, 2005: 31). Namun, dia menganggap frontier bukan sebagai suatu tempat maupun proses, melainkan sebuah "proyek" - sebuah wilayah yang dipandang sebagai kumpulan sumber daya alam yang patut dieksploitasi oleh pengusaha dan pekerja. Oleh karena itu, daerah tersebut secara spesifik merupakan frontier kapitalis, yang definisinya ditentukan oleh prospek produksi panen yang ditakdirkan sebagai komoditas.

Tsing (2005: 31-32) menyebut adanya jenis-jenisfrontier lainnya-yaitu frontier pembentukan suatu bangsa, teknologi, dan penyelamatan (salvage) - dan menggolongkan situasi di Kalimantan saat ini sebagai perpaduan dari frontier sumber daya dan penyelamatan yang ditandai dengan adanya kemunduran, produksi, dan konservasi yang semuanya dapat disaksikan berjalan di waktu yang bersamaan. Namun, penekanan Tsing atas terjadinya berbagai hal dalam waktu yang sama tersebut tidak memungkinkan adanya penelusuran terhadap bagaimana berbagai hal tersebut dapat berjalan bersamaan walaupun berada di ruang yang berbeda. Ruang yang berbeda tersebut maksudnya adalah ketika satu jenis frontier memegang peran yang lebih besar, maka jenis frontier lainnya mungkin berkurang perannya di suatu wilayah. Pendapat Tsing mengenai frontier sebagai proyek tersebut sesuai dengan orientasi Foucault mengenai bagaimana formasi diskursif membentuk jenis-jenis subjek manusia tertentu (Tsing, 2005: 30). Pendekatan ini merupakan sebagian dari latar belakang gagasan pembentukan dan pembalikan status frontier di suatu wilayah - frontierisation dan defrontierisation.

Untuk menyoroti aspek pembentukan dan pembalikan status frontier ini, penulis menggunakan dan memperluas tipologi frontier dari Danilo Geiger (2008b) dalam survei besar tentang relevansi frontier di Amerika Latin dan Asia. Geiger mendefinisikan frontier sebagai "areas remote from political centres which hold strategic significance or economic potentials for human exploitation, and are contested by social 
formations of unequal power" ("wilayah yang jauh dari pusat-pusat politik yang memegang arti strategis atau potensi ekonomi untuk eksploitasi manusia dan diperebutkan oleh formasi sosial kekuasaan yang tidak setara") (Geiger, 2008a: 78, huruf miring seperti aslinya). ${ }^{2} \quad$ Penekanannya pada "potensi ekonomi" mengingatkan kepada gagasan frontier sumber daya dari Tsing, tetapi penyebutan tambahan mengenai "signifikansi strategis" juga menyoroti dimensi politik kendali negara. Sindiran akhirnya untuk "formasi sosial kekuasaan yang tidak setara" mengulangi dan mengklarifikasi fokus awal Lattimore mengenai perbedaan sosial dan ekonomi masyarakat yang berinteraksi dalam konteks frontier. Namun, definisinya mengenai frontier sebagai suatu "wilayah", memadukan gagasan suatu daerah dengan bingkai yang dibebankan atasnya. Penulis menganggap akan lebih tepat jika frontier ditafsirkan sebagai pembingkaian suatu wilayah oleh negara atau "formasi sosial tidak setara" lainnya yang mendefinisikan ulang wilayah itu dengan cara yang memiliki konsekuensi terhadap pola-pola kendali, pemukiman, dan eksploitasi.

Atas dasar definisi ini, Geiger mengajukan tipologi tripartit dari frontier. Tipe pertama, yang jelas-jelas berangkat dari konseptualisasi Turner, adalah frontier pemukiman" (frontier of settlement). Tipe pertama ini mengacu pada suatu wilayah dapat menjadi fokus pemukiman oleh berbagai tipe migran; (1) pendatang yang secara jelas didukung oleh pemerintah, seperti pada program transmigrasi Indonesia; (2) pemukim yang bekerja dengan cara mereka sendiri tetapi

\footnotetext{
${ }^{2}$ Geiger mengulangi definisi ini di halaman 99 dari karya yang sama, dan juga memberikan keterangan yang lebih ringkas: 'daerah perbatasan adalah ruang yang dikelola secara longgar yang kaya akan sumber daya, yang didambakan oleh nonpenduduk' (Geiger,
}

difasilitasi oleh pemerintah melalui pinjaman, penyediaan alat-alat, dan pasokan lainnya di pemukiman baru; serta (3) migran spontan. Meskipun demikian, bahkan para migran spontan sering kali datang membawa dan memaksakan inovasi-inovasi yang sesuai dengan program negara tentang pembangunan di wilayah pemukiman baru mereka, seperti pertanian yang intensif, tanaman perdagangan, dan sejenisnya.

Tipe kedua, frontier ekstraksi" (frontier of extraction), sangat sejalan dengan definisi frontier sumber daya dari Tsing. Seperti yang juga ditekankan oleh Lattimore, suatu formasi sosial menentukan suatu frontier dengan merujuk pada teknologinya yang dapat menuai atau memanfaatkan apa yang kemudian diidentifikasi sebagai "sumber daya" di wilayah yang ditetapkan statusnya sebagai frontier. Proses ini seringnya dipelopori oleh penetrasi perusahaan, baik milik negara maupun swasta, dan juga oleh perusahaan transnasional yang bekerja sama dengan perusahaan dan agensi- agensi domestik negara tersebut. Hal tersebut biasanya dilakukan dengan cara perusahaan datang untuk mengambil apa yang sudah diidentifikasi sebagai sumber daya (misalnya, mineral yang diidentifikasi oleh perusahaan tambang) ataupun untuk menciptakan konstelasi ekonomi (contohnya, perkebunan monokultur berskala besar) yang dapat memanfaatkan sumber yang teridentifikasi (misalnya, jenis tanah tertentu atau habitat lainnya yang cocok untuk budidaya tersebut).

Tipe ketiga, frontier kendali" (frontier of control), adalah zona-zona yang prioritasnya

2008a: 78). Dia mengakui bahwa definisinya berasal dari spesifikasi Hvalkof (2008) yang lebih lengkap dalam esai yang nantinya berada di dalam volume yang sama. 
adalah untuk mengamankan kedaulatan dari negara atau bentuk politik yang serupa (misalnya kerajaan, kekaisaran, dan lain-lain). Zona-zona tersebut seringkali ditemukan di sekitar perbatasan nasional, tempat munculnya ancaman invasi oleh negara tetangga (misalnya, kepulauan Natuna di perbatasan Indonesia). ${ }^{3}$ Namun, frontier kendali tersebut juga dapat muncul dalam tataran internal suatu negara, seperti dalam kasus pemberontakan oleh konstituen etnis atau agama (misalnya, Jawa Barat semasa pergerakan Darul Islam).

Sebagai tambahan atas ketiga tipe di atas, penulis mengusulkan tipe keempat, yaitu frontier konservasi (frontier of conservation). Tsing memberikan penjelasan awal mengenai tipe ini dalam gagasannya mengenai frontier penyelamatan, yang dilihat sebagai koeksistensi ironis dengan frontier sumber daya. Dalam kasus Kalimantan, kawasan lindung mungkin menjadi wilayah yang disukai untuk operasi militer dan usaha lainnya yang dijalankan oleh kroni-kroni negara. Konservasi menciptakan jenis perbatasan-perbatasan baru di sekitar kawasan lindung - daerah cadangan, lahan basah, taman nasional, dan sebagainya dan zona-zona baru juga - misalnya, zona penyangga - baik yang melarang maupun yang menentukan tipe ekstraksi yang berbeda dan penggunaannya mengakibatkan transformasi hubungan antara para pribumi dan pemukim.

Frontier baru ini juga menarik "komunitas" pendatang baru, yaitu konservasionis dan para birokrat yang bekerja sama dalam mengamankan perbatasanperbatasan baru ini. Frontier konservasi, seperti halnya frontier lain, dapat terwujud secara bertahap, dengan menggunakan kawasan lindung yang sering kali ditangguhkan dalam jangka waktu yang lama dengan status

${ }^{3}$ Lihat tulisan Budiana setiawan dalam nomor khusus ini. calon kawasan, tetapi kemudian diaktifkan sebagai kawasan yang relevan secara lebih intensif ketika ambang batas tertentu telah dilalui, seperti penegasan dan pemberitahuan tentang kawasan lindung.

Sementara itu, Tsing mencatat, simultanitas lebih dari satu jenis frontier, dalam proses sejarahnya, setiap jenis bingkai frontier ini bisa menunjukkan relevansi yang berbeda. Contohnya, setelah perang, frontier suatu wilayah dapat berfungsi sebagai suatu frontier kendali, meskipun masih berfungsi juga sebagai frontier ekstraksi dan bahkan mungkin bisa diintensifkan fungsinya sebagai frontier pemukiman untuk kepentingan keamanan batas nasional. Tiap-tiap bingkai frontier ini memiliki lintasannya sendiri, baik dalam bentuk tanggapan atas kemajuan teknologi, ketegangan-ketegangan politik setempat, tekanan global, imperatif negara, maupun sejumlah kondisi lainnya. Karakterisasi seperti itu mengharuskan definisi mengenai frontier diubah supaya lebih bersifat persimpangan dari frontierisation dan defrontierisation.

Bahkan, bagi mereka yang membicarakan mengenai "pembalikan status frontier" (defrontierisation), misalnya di wilayah Barat di Amerika - kadang-kadang merujuk pada tahun 1890 (Webb, 1952: 4) - hal itu harus dianggap sebagai proses yang bertahap, bukan peristiwa yang terpisah-pisah. Namun, penulis tidak mengaitkan secara langsung defrontierisation dengan pemukiman yang mencapai ambang batas atau tingkat demografis tertentu, tetapi lebih pada keberhasilan para pribumi yang menggunakan agensi sendiri dalam menegaskan kembali kendali wilayah mereka dari pemukim, kendali perusahaan, dan instansi yang telah berusaha 
untuk mendominasi mereka (Acciaioli \& Sabharwal, 2017).

Tulisan ini berusaha mengilustrasikan kegunaan suatu pendekatan yang memiliki relevansi sangat luas dengan memfokuskan perhatian pada konteks Dataran Lindu di Sulawesi Tengah. Penulis berusaha mengonsepkan pembentukan dan pembalikan status frontier berdasarkan konsep frontierisation dan defrontierisation pada empat aspek secara menyeluruh. Keempat aspek itu adalah kendali, ekstraksi, pemukiman, dan konservasi. Tulisan ini akan mengulas lima periode sejarah yang dikategorisasikan sesuai dengan sejarah Indonesia pada umumnya dan sejarah Dataran Lindu pada khususnya. Penulis berharap bahwa pendekatan ini mampu menyingkapkan bagaimana Dataran Lindu menanggapi desakan berbagai pihak yang selalu menyerbu sejak masa prakolonial ketika posisi mereka masih sebagai daerah pinggiran kerajaan kecil hingga zaman negara-bangsa yang baru - semacam pendeskripsian sejarah relasi kuasa yang tidak seimbang (unequal power relations).

Saat ini masyarakat Lindu sebagai komunitas tinggal di kawasan yang dikelilingi oleh wilayah keanekaragaman hayati, yaitu Taman National Lore Lindu di dalam ekokawasan Wallacea (Mittermeier, et.al., 2004). Wilayah tinggal mereka tersebut memang bisa disebut sebagai jenis frontier baru, tetapi keadaan itu bisa pula memberi kesempatan kepada masyarakat Lindu untuk membalikkan relasi kuasa itu dengan kekuatan agensi mereka dan sedikit banyak memerdekakan mereka dari bingkai frontier

\footnotetext{
${ }^{4}$ Ketika digunakan untuk merujuk pada masyarakat, nama seperti itu biasanya diawali dengan to yang berarti 'orang', yaitu To Lindu. Masyarakat pribumi dari wilayah juga dapat disebut sebagai penutur bahasa Tado (To poTado).
}

yang lain. Salah satu cara yang bisa dilakukan adalah mencapai semacam kedaulatan dengan bantuan dari Aliansi Masyarakat Adat Nusantara (AMAN) dan instansi lain yang bersangkutan.

\section{Masa Prakolonial - Akhir Abad 19: Lindu sebagai Wilayah Pinggiran}

Pada masa sebelum datangnya kolonial Belanda, Lindu merupakan wilayah pinggiran yang relatif terisolasi yang baru mulai dikunjungi oleh pendatang secara bertahap dan belum memenuhi syarat untuk dikategorikan sebagai frontier. Kontak langsung dataran tinggi Sulawesi Tengah (Midden Celebes) dengan kolonialisme Belanda baru dimulai pada awal Periode Etis di tahun 1904. Sebelumnya, penetrasi ke dalam datarandataran tinggi ini hanya berupa kunjungan sejumlah kerajaan kecil (koningkjes dalam terminologi kolonial Belanda).

Meskipun sebagian besar masyarakat di pegunungan Sulawesi Tengah relatif otonom, mereka memberikan penghormatan kepada kerajaan dataran rendah Kaili yang kuat. Lindu - di sini nama ini bisa berarti tiga hal, yaitu nama dataran tinggi yang berpusat di sekitar danau dengan nama yang sama, nama kelompok etnis pribumi ${ }^{4}$ yang pertama kali menghuni dataran tersebut, ${ }^{5}$ dan nama pemerintahan yang meliputi semua pemukiman di sana (ngata Lindu) - memberikan upeti bahan pangan secara berkala (misalnya, ikan tapa) kepada Kerajaan Sigi di Lembah Palu. Sigi bisa dianggap sebagai penguasa, tidak hanya karena menuntut upeti sebagai

\footnotetext{
${ }^{5}$ Kaudern (1925) memperkirakan pemukiman awal oleh nenek moyang To Lindu telah terjadi tidak lebih awal dari tiga abad sebelumnya.
} 
pengakuan atas keunggulannya, tetapi juga menggunakan orang-orang dari kerajaan kecil pegunungan pinggiran tersebut untuk melakukan serangan terhadap kerajaan tetangganya. Lindu adalah kelompok terakhir dari kerajaan kecil yang terdaftar pada Valentijn (jilid 1, bagian b, 1724: 74). Hal itu mungkin karena Lindu merupakan bagian pinggiran jauh dari Sigi dan terdapat kompetisi memperebutkannya di antara beberapa kerajaan kecil di Lembah Palu. Dusun-dusun kecil yang melingkari dataran tersebut berada di bawah kendali para pemimpin lembaga adat dari peringkat bangsawan turun- temurun (maradika), tetapi tidak memiliki kepemimpinan seorang raja atau magau yang lebih terpusat, seperti yang dimiliki Sigi dan kerajaan-kerajaan kecil dataran rendah yang lain.

Pengamatan Kapten van der Hart (1853) selama pelayaran mengelilingi pulau Sulawesi untuk membujuk para raja setempat agar memenuhi kuota upeti emas mereka kepada pemerintah kolonial mengungkapkan kemiskinan yang relatif terdapat di semua raja setempat, jumlah pengikut yang sedikit, dan terbatasnya kapasitas pasukan dan sumber daya dari daerah-daerah pedalaman seperti Lindu. Hubungan utama Lindu sehari-hari adalah dengan kerajaan kecil pengikut yang berada dalam situasi yang serupa di pegunungan, misalnya Kulawi di barat daya dan Lore di timur. Maradika To Lindu secara berkala menikah dengan para bangsawan dari kedua wilayah tersebut (Kaudern, 1940: 14), tetapi terkadang perselisihan mengenai mas kawin dan penghinaan lainnya menyebabkan mereka

${ }^{6}$ Seperti halnya Adriani dan Kruyt sebelum mereka, sepupu Sarasin dari Basel terkesan selama kunjungan mereka ke Lindu dari tanggal 20-14 (14- 20?) Juli tahun 1903 dengan balai desa/kuil atau lobo di pulau Lewuto (Bola) di Danau Lindu. Akan tetapi, mereka juga ketakutan mengetahui bahwa sekelompok pria saling merampok; tangkapan perang secara berkala dijadikan budak (batua) yang diperlukan untuk pengorbanan ritual pada upacara-upacara komunitas dan ritual-ritual siklus hidup (Kruyt, 1898, 1938). ${ }^{6}$

Berdasarkan hal itu, selama periode prakolonial, Lindu dengan anggota komunitas awalnya, mungkin paling tepat digolongkan sebagai wilayah batas luar yang belum mengalami pendudukan dan ekstraksi serta belum tepat jika dikategorikan sebagai daerah frontier. Meskipun masyarakat Lindu menyerahkan upeti secara berkala pada suatu kerajaan, tetapi tidak ditemukan pemukiman skala besar dari suatu komunitas kerajaan kecil di seluruh Lembah Palu. Jika mengacu pada tipologi frontier menurut Geiger, upeti hanya dianggap sebagai mode ekstraksi yang paling dangkal, yang hanya diindeksasi sebagai suatu kendali politik yang sangat lemah yang diterapkan oleh kerajaan kecil dataran rendah.

\section{Tahun 1898 - 1945: Masa Kolonial}

Penetrasi kolonial di dataran tinggi bagian barat Sulawesi Tengah melalui intervensi militer langsung baru dimulai dengan sungguh- sungguh dengan dicanangkannya Periode Etis di Hindia Belanda pada tahun 1901. Penaklukan daerah Kaili oleh Belanda dimulai di tahun 1902, ketika berbagai magau dari kerajaan dataran rendah Sigi, Palu, dan Tawaeli ditekan oleh organisasi militer Belanda agar mengizinkan ekspedisi para naturalis, Swiss Fritz dan Paul Sarasin, untuk melakukan survei daerah pedalaman (Klerck,

Lindu kemudian keluar melakukan perjalanan menemukan korban manusia untuk dikorbankan di lobo ini sehingga bangsawan yang baru saja meninggal dapat dikubur dengan penuh kehormatan (Sarasin \& Sarasin 1905). 
jilid 2 1938: 43; Sarasin \& Sarasin, 1905; lihat juga Mailrapporten 1902, dokumen 690). ${ }^{7}$

Setelah Sigi menyerah di tahun 1904 dengan penangkapan dan pengasingan magaunya, Kulawi pun mulai runtuh. Pemerintah Hindia Belanda (NEI) mulai mengkonsolidasi pemerintah setempat di dataran-dataran tinggi, yang menghapuskan otonomi lembaga ngata dan mempersatukan semua desa-desa pegunungan di bawah kepemimpinan zelbestuurder tunggal (suatu administratur "otonom" secara harfiah), yang diberikan gelar magau sejajar kebiasaan dataran rendah Kaili (Kruyt, jilid 1, 1938: 14; Kaudern, 1940: 35). Hal tersebut seperti yang disebut oleh Lattimore sebagai penciptaan "kepala" baru di wilayah frontier dengan menggunakan kekuatan politik yang menempatinya. Dataran Lindu kemudian dimasukkan dalam cakupan otoritas pemimpin tersebut - magau Kulawi ketiga, Lakuntu Tomai Mampo, merupakan keturunan Lindu. ${ }^{8}$

Catatan umum tahun-tahun berikutnya menghasilkan suatu gambaran "dislokasi dan kemerosotan moral yang cepat dan besarbesaran" pada kelompok dataran tinggi dan, menurut sejumlah sumber, "runtuhnya" budaya tradisional (Davis, n.d.a.: 90). Terlepas dari benar atau tidaknya hal tersebut, Dataran Lindu yang masuk dalam wilayah magau Kulawi yang baru secara garis besar tetap berfungsi sebagai frontier kendali sepanjang era kolonial. Sesuai dengan kebijakan pemaksaan perpindahan para peladang untuk bermukim

\footnotetext{
7 Dengan perhatian komunitas ilmiah dunia atas ekspedisi Sarasin di tahun 1902, Pemerintah Hindia Belanda tidak mampu memberikan kesan bahwa hanya melakukan kendali nominal di daerah pedalaman yang dimilikinya. Meskipun ekspedisi ini tidak diluncurkan untuk kepentingan konservasi, penelitian sejarah alam yang telah dimulai menetapkan fondasi awal membingkai daerah Lore- Lindu sebagai bagian dari kawasan konservasi delapan puluh tahun kemudian.
}

kembali di desa-desa permanen, pemerintahan Hindia Belanda (NEI) memang memindahkan semua penduduk Lindu dari pondok terpencil mereka di antara sawah dan kebun kering di bukit-bukit sekitarnya ke tiga desa inti di sekitar danau (Davis, n.d.b.: 3). Peningkatan infrastruktur budidaya sawah menjadi prioritas pemerintah NEI (Boonstra van Herdt, 1914: 626). ${ }^{9}$

Belanda juga memperkenalkan penanaman kopi kepada para penduduk dataran tinggi sehingga mereka memiliki tanaman perdagangan yang memungkinkan mereka untuk membayar pajak. Hal itu membuat fungsi Lindu dan area- area sekitarnya diintensifkan sebagai frontier ekstraksi. Untuk memudahkan transportasi barang-barang seperti beras dan kopi, beberapa upaya pembangunan jalan alternatif ke Lindu yang menggantikan jalan dari Kulawi dilakukan oleh kolonial Belanda. Hal itu dilaksanakan karena pada pertengahan tahun 1930-an, sebagian besar jalan yang menuju ke Dataran Lindu dari jalan utama antara Palu dan Kulawi hanya dapat dilalui dengan kuda (Vorstman, n.d.: 10-11).

Akan tetapi, penemuan terkait di tahun 1930-an menyebutkan bahwa Dataran Lindu terinfeksi oleh siput yang mengandung schistosoma yang menyebabkan penyakit schistosomiasis (Whitten, Mustafa \& Henderson, 1987: 289) dan menghalangi segala upaya lebih lanjut untuk meningkatkan akses sampai ada istilah "jalan kuda tidak akan ditingkatkan hingga awal milenium ketiga".

\footnotetext{
${ }^{8}$ Para informan Lindu bersikeras bahwa posisi magau di Kulawi pertama kali ditawarkan kepada seorang bangsawan Lindu, dan hanya setelah penolakannyalah diberikan kepada maradika Kulawi Tomai Rengke, pemimpin pasukan lawan yang sebelumnya.

9 Para misionaris Belanda Adriani dan Kruyt telah menemukan irigasi sawah yang sangat sederhana waktu mereka mengunjungi dataran Lindu sebagai orang Barat yang tercatat pertama di tahun 1898 (Adriani, 1898; Adriani \& Kruyt, 1898).
} 
Penemuan ini menjadi sebab utama yang menggagalkan frontierisation lebih lanjut di Lindu, yang tetap kurang terintegrasi dengan kerajaan lain di dataran tinggi dan lembah sepanjang sisa periode kolonial dan dengan demikian kurang sesuai dengan kriteria pemukiman sebagai frontier untuk orang-orang luar.

Meskipun demikian, Lindu memang menjadi terintegrasi ke dalam kendali kolonial melalui satu cara, yaitu melalui upaya misionaris (bandingkan Aragon, 2000). Belum menjadi frontier pemukiman, dan hanya secara garis besar tunduk pada ekstraksi yang lebih besar dibandingkan dengan masa prakolonial, Lindu adalah bagian dari frontier misionaris yang didorong oleh pemerintah kolonial Belanda dan dengan demikian merupakan sejenis frontier kendali yang baru dimunculkan. Setelah pendirian kampung Kalawara na Puti di Lembah Palu oleh para transmigran Jawa Tengah dengan perlindungan dari petugas Bala Keselamatan di tahun 1900, para opsir Bala Keselamatan seperti Kolonel Leonard Woodward dan Kapten Edward Rosenlund memulai perjalanan ke pegunungan dan akhirnya tinggal lama di wilayah itu dan sekitarnya (Brouwer, 1977; Caddy, 1982; Vlaardingen, 1937). Pada kesempatan tersebut mereka mulai melakukan konversi sejumlah besar komunitas pegunungan ke dalam agama Kristen.

Melalui pembangunan rumah ibadah, sekolah, klinik dasar dan cara hidup kebaktian, pertemuan doa, serta "mukjizat-mukjizat" lain, para petugas Bala Keselamatan, yang menunjukkan anugerah mereka yang unggul

10 Pengaruh pandemik Flu Spanyol (1918- 1920) di seluruh dunia yang menyerang pedalaman Sulawesi (Henley, 2005: 263) juga harus dipertimbangkan sebagai unsur konversi juga. Bahkan di area yang jauh seperti Lembah Rampi atau Masamba, yang terletak di pegunungan beberapa hari berjalan kaki dari Palu,
(Aragon, 1996b), berhasil mengubah para pemimpin desa (maradika) menjadi penganut dalam agama ini. ${ }^{10}$ Pada pertengahan tahun 1930-an, Bala Keselamatan telah memiliki anggota sebanyak 296 petugas, yang tersebar di 199 pos di seluruh Sulawesi (Klerck, jilid 2, 1938: 527). Pada tahun 1942, di Sulawesi Tengah saja Divisi Komandan Woodward mengelola jaringan sebesar 140 korps dan cabang korps, 19 sekolah, 5 klinik medis, dan 66 petugas, yang kebanyakan dari mereka pada awalnya telah menjadi penganut agama Kristen di daerah Pipikoro, Kulawi, dan sekitarnya (Brouwer, 1977: 60). Para opsir Bala Keselamatan bertugas sebagai panutan dan perantara budaya (Haba n.d. [2001]) yang memperlebar kendali kolonial yang mendisiplinkan jemaat. Para jemaat itu mengungkapkan penghargaan mereka kepada kolonial Belanda atas transformasi yang mereka alami sehingga mereka bisa menjadi kaum yang "beradab". Pernyataan itu merupakan ungkapan yang biasa diutarakan oleh masyarakat "tradisional" sebagai subjek baru rezim kolonial.

Pendudukan Jepang yang dimulai tahun 1942 meneruskan sebagian besar kebijakan yang ada pada periode kolonial Belanda. Lindu tetap relatif terisolasi, dengan hanya dua prajurit Jepang yang ditempatkan di wilayah ini sepanjang masa perang. Beberapa wilayah tetangga mengalami dampak yang lebih intensif dari pendudukan Jepang, seperti pemaksaan kerja dalam suatu operasi untuk pertambangan mika di Kulawi (Aragon, 1996a). Namun, frontierisation Lindu dalam hal ekstraksi diintensifkan oleh angkatan

lebih dari tiga perempat penduduknya meninggal. Seperti yang penulis biografi Rosenlund tunjukkan, flu ini 'cukup menurunkan moral, mereka jelas siap apabila seseorang menuntun mereka ke dalam hidup yang baru dan lebih baik’ (Caddy, 1982: 17). 
bersenjata Jepang untuk Kawasan Kemakmuran Bersama Asia Timur Raya yang mereka jatuhkan. Hal itu dilakukan Jepang dengan mengambil semua cadangan makanan, termasuk sebenarnya banyak yang perlu untuk kebutuhan subsistensi, dibawa untuk mendukung upaya perang kekaisaran Jepang. Bahkan, semua pakaian dan tekstil apa pun yang ditemukan oleh Jepang ${ }^{11}$ kemudian diambil. Hal itu yang memaksa para penduduk Lindu kembali membuat dan mengenakan pakaian dari kulit kayu. Dalam sejumlah hal, pengaruh dua kolonial tersebut, Belanda dan Jepang, tidak hanya mengokohkan penundukan Lindu sebagai frontier kendali, tetapi juga melanjutkan proses pemukiman oleh orang yang bukan penduduk dataran tinggi. Hal itu ditandani dengan datangnya para misionaris yang mengintensifikan pembukaan Lindu sebagai frontier dengan kedatangan para pendeta, guru, petugas kesehatan, dan lain-lain.

\section{Tahun 1945-1967: Kemerdekaan Lore Lindu di Era Orde Lama}

Setelah periode singkat defrontierisation awal yang muncul dari pengabaian negara, segera setelah kemerdekaan, pemberontakan regional meningkatkan frontierisation Lindu. Proses ini berkenaan dengan kendali, khususnya disebabkan efek intervensi militer di area-area sekitarnya - meskipun, ironisnya, pergerakan pengungsi internal (IDPs) ke Lindu tidak hanya meningkatkan frontierisation di segi pemukiman, tetapi juga meningkatkan

\footnotetext{
11 Kebanyakan tekstil ikat tradisional (mbesa) yang digunakan untuk transaksi mahar (oli) dan sebagai pembungkusan mayat (pobungu to mate) dikubur oleh masyarakat Lindu untuk menghindari pengerukan Jepang.

12 Istilah Permesta adalah singkatan dari Perintah Perang Semesta (The Order of Total War), yang mengesahkan operasi revolusioner untuk membunuh
}

Lindu sebagai frontier ekstraksi. Sejak tahun 1950-an hingga pertengahan 1960-an, perang gerilya memberikan dorongan yang paling signifikan terhadap pergerakan penduduk di Sulawesi.

Setelah pemberontak Qahhar Mudzakkar di Sulawesi Selatan menggabungkan dirinya dengan gerakan separatis Darul Islam (Harvey, n.d.; Jackson, 1980), gerombolan - istilah lokal untuk masa perang gerilya - ini menyebar melalui pegunungan dan lembah Sulawesi Selatan, Tenggara, dan Tengah. Pasukan gerilya itu menghukum mati para penganut animisme dan Kristen, bahkan Islam yang tradisional/ heterodoks. Setelah gerilya itu mencapai dataran rendah Kaili dan pegunungan di sekitarnya, daerah ini menjadi frontier kendali yang sangat intensif, dengan pasukan pemerintah dikirim untuk meredam pasukan separatis pada daerah operasional pinggiran bagian utara. Selain itu, wilayah ini juga ditetapkan sebagai frontier kendali ketika wilayah Kaili juga menandai perbatasan selatan dari pemberontakan separatis Permesta, ${ }^{12}$ serta pemberontakan wilayah lainnya yang berasal dari Sulawesi Utara. Lebih lanjut, wilayah ini juga menjadi frontier kendali ketika ada gejolak sayap kiri (Komunis) dan di masa pemerintahan nasional Soekarno (Harvey, 1977).

Kondisi tersebut kemudian memaksa munculnya fungsi Lindu sebagai frontier pemukiman yang membentang di sekitar wilayah kerajaan sampai batas luar pegunungan bagian tenggara. Selanjutnya,

semua pria, wanita dan anak-anak yang tidak membantu kelompok gerilya secara aktif (Jackson, 1980: 17). Meskipun dikeluarkan pada tanggal 11 Juni tahun 1961 oleh Darul Islam, singkatan untuk perintah tersebut - Permesta - mulai menjadi lebih terkait sebagai label dengan pergerakan separatis di Sulawesi Utara yang didominasi oleh orang-orang Kristen Minahasa. 


\section{Kasus Dataran Lindu Di Sulawesi Tengah}

wilayah Lindu diatur ulang menjadi sebuah kecamatan (subdistrik). Pengungsi yang kabur dari Permesta dari utara mulai bergerak ke Lindu selama tahun 1950-an, kemudian berdatangan pula pengungsi dari Pada- Seko, Rampi, dan kelompok etnis Kristen lainnya. Mereka berasal dari dataran tinggi Sulawesi Selatan bagian utara dan bermukim di Sulawesi Tengah bagian barat, termasuk di wilayah Lindu. ${ }^{13}$ Selain itu, ada pula arus pengungi berupa masyarakat Islam Bugis yang tiba dari Sulawesi Selatan.

Orang Bugis tersebut mulai mendiami Dataran Lindu sebagai pemukim di awal tahun 1950-an. Mereka merupakan pengungsi yang melarikan diri dari pemberontakan Qahhar Mudzakkar di Sulawesi Selatan. Para migran ini segera memulai proses migrasi berantai dengan membawa sanak keluarga agar membantu berkembangnya usaha ekonomi mereka (Acciaioli, 1999; 2000). Hal itu kemudian membentuk sebuah "formasi sosial" baru yang berlawanan secara signifikan dengan ngata yang berorientasi subsistensi dari para pribumi To Lindu. Orang- orang Bugis datang dari berbagai wilayah di jantung Sulawesi Selatan - Wajo', Sidenreng- Rappang (Sidrap), Soppeng, Bone, Pangkajene Kepulauan (Pangkep), dan kawasan lainnya - dan mereka berhasil mempertahankan identitas wilayah subetnis mereka dengan baik dari tahun 1980an dan sesudahnya. Sejak saat itu, Lindu muncul pada skala besar sebagai frontier pemukiman.

\footnotetext{
${ }^{13}$ Selain sebagai pengungsi internal, orang Minahasa dari Sulawesi Utara sudah mulai datang sebelumnya sebagai guru di sekolah yang dibangun oleh Bala Keselamatan.

14 Transformasi danau oleh Departemen Perikanan menjadi satu set baru sumber daya yang mencontoh tindakan 'kepanjangan akal daya' yang disebut oleh
}

Kompleksitas skala dan teknologi usaha yang dibangun oleh orang-orang Bugis juga membuat Lindu berfungsi sebagai frontier ekstraksi. Hal itu terjadi karena adanya pemasaran sumber daya dari Danau Lindu, pembukaan lahan sawah, dan kebun tanaman perdagangan. Frontierisation ekstraktif ini diteruskan oleh negara sebagai bagian dari frontierisation pembangunan yang lahir kemudian dari wilayah ini. Departemen Perikanan memasukkan beberapa jenis ikan ke Danau Lindu mulai tahun 1951, termasuk mujair (tilapia mossambica sp) sebagai jenis yang paling signifikan. Meskipun "pembibitan" danau ini $^{14}$ dimaksudkan untuk membantu perkembangan mata pencaharian $T o$ Lindu, meningkatkan pendapatan mereka, dan menghubungkan mereka melalui pertukaran komoditas dengan wilayah yang lebih luas, tetapi masyarakat Lindu belum mampu menanggapi sepenuhnya sumber daya baru ini karena ketiadaan penyediaan teknologi penangkapan ikan yang cocok.

Sebaliknya, orang Bugis mampu membawa jaring insang nilon (landak) dari Selatan dan mengerahkan sanak saudara mereka sebagai klien nelayan untuk memanen sumber daya baru ini. Hanya sedikit keluarga Lindu yang mampu mengupayakan membeli landak dari orang Bugis pada harga yang dibebankan (empat puluh kali lipat biaya mereka di Sulawesi Selatan), dan pada masa itu usaha memancing jenis ikan lain - misalnya ikan gabus (Channa striata) - juga mulai didominasi oleh para migran Bugis. ${ }^{15}$ Orang-

Tsing (2005: 30) sebagai unsur dalam etiologi asal frontir kapitalis di Kalimantan Selatan.

${ }^{15}$ Di samping penggunaan landak untuk menangkap mujair, orang Bugis lain membawa teknologi lain yang tidak dikenal oleh To Lindu, seperti jala, yang mereka gunakan untuk menangkap karper (yaitu ikan emas atau Ciprinus carpio), tawes (Puntius javanicus), dan gurame (Osphronemus gurame), yang sudah 
orang Bugis menyempurnakan transformasi ini dengan membangun sistem pemasaran ikan yang kompleks, dengan para pemasar Bugis yang berjualan di Palu dan menggerakkan jaringan klien nelayan mereka di Lindu (Acciaioli, 2000). Tidak hanya sistem ini menunjukkan dominasi suatu formasi sosial yang inkursif, tetapi juga menunjukkan keterlibatan orang-orang Bugis dalam memperkenalkan tujuan negara di bidang pembangunan dan "mensosialisasikan" pembangunan itu kepada "masyarakat terasing" sebuah kategori yang digunakan oleh Departemen Sosial pada masa itu untuk menamakan kelompok-kelompok seperti To Lindu di area pinggiran Indonesia. Jadi, Lindu semakin kena frontierisation dalam hal ekstraksi dan pemukiman, selain juga kendali.

\section{Tahun 1967-1998:}

\section{Masa Pembangunan Imperatif Orde Baru}

Inisiasi Orde Baru dengan pengambilan kekuasaan oleh Mayor Jenderal Soeharto pada periode transisi tahun 1965-1967 ditandai dengan orientasi umum ke percepatan modernisasi; pembangunan masif menjadi legitimasi rezim yang baru. Akibatnya, Lindu dan wilayah pinggiran serupa mengalami peningkatan penetrasi dan mengalami frontierisation di semua aspek. Hal itu terutama dilakukan dengan penerapan intensif perkembangan ekonomi (misalnya melalui suksesi program peningkatan beras - Bimas, Inmas, dan lain-lain) oleh negara. Perkembangan itu selanjutnya meningkatkan ekstraksi dan pemukiman di daerah ini. Proses

dikenalkan bersama dengan mujair (tilapia mossambica) oleh Departemen Perikanan (Whitten, Mustafa \& Henderson, 2002: 298; Watling \& Mulyana, 1981: 65).

${ }^{16}$ Dasar dari sistem administrasi desa yang seragam ini ditetapkan melalui dua peraturan perundang- ini disertai dengan meningkatnya kendali ketika Orde Baru berusaha memaksakan pengembangan budaya (Acciaioli 1985; Jones, 2013) yang sesuai dengan standar peradaban Jawa (Pemberton, 1994) dan homogenisasi semua struktur administratif, termasuk pendirian kawasan lindung yang menandai terjadinya frontierisation konservasi di Lindu.

Kebijakan yang Orde Baru terapkan adalah memasukkan Indonesia Bagian Luar sebagai frontier kendali - suatu daerah yang tunduk pada program pembangunan dan peningkatan (Li, 2007). Namun, program "perbaikan" ini dilengkapi dengan dukungan resmi melalui lisensi operasi perusahaan swasta skala besar (yaitu kroni kapitalisme) yang mengintensifkan ekstraksi. Sistem administratif desa yang seragam diwajibkan di seluruh Indonesia yang mencontoh pada desa di Jawa $^{16}$ dan dengan demikian menghilangkan pula partisipasi resmi lembaga adat yang berakibat pada berkurangnya pula otonomi dan cakupan agensi dari masyarakat.

Pengalaman Lindu mengenai perubahan ini mencontohkan dampak kebijakan di daerah lain di Indonesia. Dinas Pertanian lokal memperkenalkan berbagai program peningkatan tanaman, yang tidak hanya berfokus pada beras, tetapi juga jagung dan tanaman dataran tinggi lainnya yang dianggap "cocok". Departemen Sosial dan Departemen Pendidikan dan Kebudayaan membatasi ruang lingkup adat dengan menentukan apa yang merupakan isi adat yang sah di "masyarakat terasing" tersebut seperti To Lindu (Acciaioli, 1985:153). Para pemimpin adat tidak lagi diizinkan untuk mengadili sengketa tanah dan

undangan: Undang-undang Nomor 5 Tahun 1974 tentang Pokok-pokok Pemerintahan di Daerah dan Undang-undang Nomor 5 Tahun 1979 tentang Pemerintahan Desa. 
mesti membatasi kegiatan mereka hanya pada beberapa hal. Hal- hal yang masih menjadi wewenang pemimpin adat antara lain mengawasi perundingan mas kawin dan mahar di upacara perkawinan, berdandan dalam pakaian adat untuk menyambut pejabat pemerintah, menghibur turis, dan berpartisipasi dalam festival "menampilkan" budaya dengan kata lain adat dijadikan sebagai seni saja. Domestikasi bidang lingkungan adat mewujudkan proyek Orde Baru dalam menguasai pemerintah daerah tersebut merupakan bagian dari fungsi frontier kendali. Kepala desa yang diangkat lebih banyak yang dipilih dari pensiunan perwira militer ketimbang bangsawan lokal (maradika) yang bagian dari hirarki adat.

Para migran Bugis menganggap danau dan lahan sekitarnya sebagai sistem akses terbuka (open access) dan mereka memaksimalkan pengambilan ikan sehari-hari dengan semua teknik yang bisa mereka gunakan, termasuk pemakaian peralatan strom dari tahun 1990-an. Selain itu, mereka membuka sawah dan kebun semaksimal modal dan kemungkinan tenaga kerja mereka yang tersedia. Mereka tidak menghiraukan ketentuan adat To Lindu - yang semakin terkikis oleh pemerintah Indonesia - yang sebelumnya mengatur danau dan lahan sebagai sumber milik bersama (commons) (Ostrom, 1990) sebelum munculnya pendatang di tahun 1950an (Acciaioli, 2009).

Eksploitasi sumber daya oleh kelompok pendatang dalam rezim akses terbuka yang dipercepat seperti itu semakin mengintensifkan frontierisation Lindu yang menyangkut ekstraksi. Pada tahun 1970-an, orang Bugis telah mendirikan dominasi ekonomi di dataran, pertama dengan berhasil memasarkan ikan Danau Lindu dan kemudian menggunakan dana usaha tersebut untuk memperoleh tanah dari To Lindu melalui berbagai transaksi "ganti rugi”, yang kemudian dengan cepat dikonversi menjadi kepemilikan tanah dengan mendapatkan sertifikat tanah dari Badan Pertanahan Nasional. Orang Bugis mendirikan petak sawah di lahan yang diairi dekat danau dan kebun di hutan sekitarnya, tempat mereka menanam tanaman perdagangan - kopi, cengkeh, kemudian vanili dan kakao. Beberapa orang Bugis membuka kios dan beroperasi sebagai pemasar perantara produk tidak hanya dari sesama pendatang Bugis tetapi juga dibeli (dengan harga rendah) dari To Lindu dan migran lainnya ke daerah.

Kelunturan adat To Lindu dan intensifikasi kegiatan kewirausahaan migran yang melakukan "pembangunan liar" itu disebut Tsing sebagai karakteristik frontier sumber daya kapitalis. Para migran Bugis sebagian besar mengatur urusan mereka melalui keadilan masyarakat mereka sendiri misalnya, hukuman yang diberikan kepada sesama nelayan Bugis jika ketahuan mencuri, serta sanksi paling berat yang diberikan adalah pengasingan dari Dataran Lindu. Pemaksaan wewenang pemerintah desa oleh negara serta invasi masyarakat Bugis pada adat Lindu, khususnya dalam eksploitasi sumber daya danau, pada akhirnya membawa konsekuensi ekologis yang buruk: menipis dan - pada akhirnya - musnahnya semua ikan mujair di danau Lindu (Acciaioli, 2009).

Bahkan, perubahan tata kelola lingkungan pada akhirnya menyebabkan pembalikan lintasan frontierisation yang baru mulai di Lindu. Ironisnya, meskipun eksploitasi sumber daya yang diintensifkan ini diamanatkan oleh tujuan pembangunan, Orde Baru juga mulai "memperhatikan" isu-isu lingkungan. Hal itu bisa dilihat dari banyaknya kawasan hutan yang dijadikan sebagai kawasan lindung. Cribb (n d.: 26, 36), misalnya, 
menghubungkan upaya pendirian kawasan lindung itu dengan usaha pemerintah mengkonsolidasikan dan memperluas kendali birokrasi, serta menegaskan kembali legitimasi pemerintah. Hal itu dilakukan karena pemerintah khawatir liberalisasi ekonomi akan melemahkan pemerintah dari kekuasaan regulasi, terutama di daerah frontier ekstraksi sumber daya. Dengan demikian, pada 1970-an, bagian-bagian besar dari Hutan Negara semakin ditetapkan sebagai cagar alam, suaka margasatwa, taman rekreasi alam, taman hutan penuh, hutan lindung, dan, mulai tahun 1980an, taman nasional. Bahkan, saat ekstraksi kapitalis dan kendali pusat semakin meningkat, jumlah frontier konservasi juga meningkat di seluruh Indonesia.

Ditetapkan sebagai cagar biosfer oleh UNESCO pada tahun 1977 (Sangaji, et.al., 2004: 17), wilayah Lore Lindu menjadi sasaran bingkai konservasi yang baru oleh deklarasi seri kawasan lindung di area tersebut - Suaka Margasatwa Lore Kalamanta pada tanggal 20 Oktober 1973; Hutan Wisata dan Hutan Lindung Danau Lindu pada 25 Januari 1978; dan Suaka Margasatwa Sungai Sopu-Sungai Gumbasa pada 10 November 1982 (Taman Nasional Lore Lindu, 2004: 1). Namun, menyadari kebutuhan bagi struktur yang lebih terintegrasi, Direktorat Konservasi Alam Indonesia meminta bantuan dalam perencanaan taman nasional dari United Nations Food and Agriculture Organization (FAO) dan World Wildlife Fund (WWF). ${ }^{17}$ Kerja sama tersebut kemudian memunculkan draf rencana manajemen FAO untuk Taman Nasional Lore Kalamanta (Blower, et.al., 1977) dan rancangan rencana WWF untuk Taman Nasional Lore Lindu, yang mengintegrasikan

17 Belakangan, organisasi ini mengubah namanya (kecuali untuk cabang AS) menjadi Worldwide Fund ketiga kawasan lindung yang tersebut (Watling dan Mulyana, 1981).

Pencarian pemerintah Indonesia akan legitimasi dalam mengakomodasi tekanan internasional untuk konservasi terbukti pada saat menjadi tuan rumah konferensi internasional tahun 1982 tentang taman nasional, International Union for the Conservation of Nature and Natural Resources (IUCN), dan deklarasi selanjutnya pada tahun itu lebih dari tiga puluh calon taman nasional, di antaranya Taman Nasional Lore Lindu. Meskipun suksesi kawasan lindung telah dideklarasikan dan dimulai di wilayah tersebut dan selanjutnya mengintensifkan frontierisation konservasi, Taman Nasional Lore Lindu tetap dengan status calon sampai dinyatakan taman nasional tahun 1993, lalu dideklarasi ulang pada tahun 1999 dengan batas- batas yang dikurangi untuk mengakomodasi daerahdaerah enklave dan pemukiman manusia lainnya di batas luarnya.

\section{Tahun 1990an - Sekarang:}

\section{Otonomi Daerah, Gerakan Masyarakat Adat, dan Kecamatan Konservasi}

Periodisasi akhir yang dipilih adalah mulai akhir tahun sembilan puluhan, yang ditandai dengan munculnya pelaksanaan agensi oleh masyarakat lokal dari daerah frontier ini dan, oleh karena itu, inisiasi defrontierisation terdapat pada setidaknya beberapa dimensi. Dengan runtuhnya Orde Baru sebagai akibat krisis keuangan Asia Tenggara setelah devaluasi baht Thailand pada tahun 1997, salah satu langkah pertama era Reformasi di Indonesia adalah dibuatnya undang-undang Otonomi Daerah (UU No. 22 dan UU No. 25) pada tahun 1999. Pemberian otonomi daerah

for Nature, meskipun tetap mempertahankan singkatan WWF. 


\section{Kasus Dataran Lindu Di Sulawesi Tengah}

merupakan penarikan sebagian dari frontier kendali yang dulu merupakan pembesaran pengusasaan Orde Baru, terutama di luar Jawa, seperti Sulawesi.

Konsekuensi tak terduga dari otonomi daerah adalah pembagian tak terkendali atas unit administrasi yang telah ada menjadi unitunit baru - provinsi kabupaten, kecamatan bahkan desa-desa - dalam proses yang dinamakan pemekaran. Di beberapa daerah, hal ini merupakan upaya yang dilakukan oleh masyarakat setempat yang menganggap diri mereka sebagai putera daerah atau masyarakat adat untuk membangun kembali kendali mereka sendiri atas wilayah mereka - sebuah proses yang Cribb (2019) namakan cantonisation (wilayah-isasi). Tindakan ini diadakan untuk mengurangi penguasa dari luar (misalnya, birokrat dari Lembah Palu) yang mengerahkan kendali politik dan kelompok migran yang berorientasi kewirausahaan (misalnya Bugis) dan di beberapa daerah melakukan dominasi ekonomi selama Orde Baru.

Cantonisation tersebut menyebabkan munculnya kekerasan sektarian di beberapa daerah, khususnya Maluku, Maluku Utara, Kalimantan Tengah, dan Sulawesi Tengah. Meskipun kekerasan itu sebagian timbul dari dinamika baru persaingan politik di antara elit (Klinken, 2007), episode ini juga terkait dengan perjuangan kehidupan orang-orang biasa (Li, 2007), terutama persaingan antara anak daerah dan pendatang (Acciaioli, 2001; Jones, 2019). Para pribumi berusaha untuk menggulingkan dominasi ekonomi dari para migran, yang telah membeli tanah mereka selama Orde Baru dan krisis ekonomi regional. Dalam kerangka pikiran penulis, konflik ini mewakili upaya lokal untuk menutup frontier kendali, pemukiman, dan ekstraksi yang ada sepanjang Orde Baru dan di permulaan era Reformasi kemarin ketika peluang untuk mendapatkan keuntungan di tingkat lokal berkembang.

Sebagian dari pembentukan unit-unit administratif baru melalui proses pemekaran ini juga merupakan upaya masyarakat setempat untuk memfasilitasi upaya mereka dalam merebut kembali kendali lokal atas sumber daya di wilayah mereka dan atas pola pemukiman. Dengan kata lain, memulai kembali pembingkaian daerah mereka dalam hal penutupan frontier kendali, pemukiman, dan ekstraksi - yaitu defrontierisation. Upaya tersebut memiliki implikasi terhadap pemukiman, seperti konflik di Kalimantan Tengah dan Maluku yang mengakibatkan ribuan keluarga migran asal Madura di Kalteng dan Buton, Bugis, dan Makasar di Maluku, melarikan diri kembali ke daerah asal mereka. Kejadian tersebut merupakan suatu contoh defrontierisation yang menutup pemukiman.

Peristiwa di Lindu juga menunjukkan pola defrontierisation dalam hal kendali, ekstraksi, dan pemukiman. Hal itu ditunjukkan dengan usaha redefinisi istilah konservasi. Redefinisi ini dilakukan dengan menggunakan pengaturan konservasi lokal sebagai kendaraan bagi To Lindu untuk berusaha mendapatkan kembali kendali atas tanah air mereka serta membalikkan dominasi Bugis dan migran lainnya. Mobilisasi To Lindu di bawah naungan konservasi sebenarnya telah tercatat sejak awal tahun sembilan puluhan, ketika aliansi yang dikepalai Gubernur Sulawesi Tengah pada akhir tahun 1980-an, berbekal dana dari Bank Pembangunan Asia, mengumumkan pembangunan sebuah bendungan Pembangkit Listrik Tenaga Air (PLTA) di muara Danau Lindu.

Langkah ini mengharuskan pemindahan semua orang dari Dataran Lindu, karena waduk air di belakang bendungan akan membanjiri semua desa dan sawah. To Lindu beraliansi dengan LSM Yayasan Tanah Merdeka yang 
berbasis di Palu berhasil menahan rencana PLTA itu (Sangaji, 2000), dengan mengajukan argumentasi ketidakcocokan adanya bendungan PLTA di tengah-tengah taman nasional. Mereka dengan demikian mampu menyelaraskan bingkai Lindu sebagai frontier konservasi dengan kepentingan masyarakat untuk membalikkan usaha pemerintah dalam membuang semua orang Lindu - termasuk To Lindu asli, orang Bugis, orang Winatu, dan pemukim lain. Tujuan dari pembanguan bendungan tersebut sebetulnya adalah mengintensifkan Lindu sebagai frontier kendali dan ekstraksi (yaitu, ekstraksi energi).

Berangkat dari keberhasilan itu, To Lindu menjadi "kesayangan" gerakan masyarakat adat yang berkembang di Indonesia ( $\mathrm{Li}$, 2000), yang muncul sebagai kekuatan yang efektif untuk mengatalisasi defrontierisation. Dorongan dari AMAN sebagai payung gerakan masyarakat adat dalam memfasilitasi usaha supaya wilayah To Lindu tidak lagi dikendalikan oleh instansi pemerintah pusat, para migran kewirausahaan, dan perusahaan kapitalis internasional, melainkan sebagai daerah di bawah kendali masyarakat adat sendiri bisa dibilang sukses. To Lindu muncul sebagai pemimpin dalam upaya serupa untuk seluruh Sulawesi Tengah, dengan pelantikan seorang To Lindu sebagai kepala organisasi masyarakat adat provinsi (Aliansi Masyarakat Adat Sulawesi Tengah atau AMASUTA) dan To Lindu lain yang bertugas sebagai wakil AMAN pada tingkat provinsi.

Setelah memperoleh manfaat bersekutu atas alasan konservasi, To Lindu dengan gembira berpartisipasi dalam proses penyelesaian kesepakatan konservasi masyarakat (community conservation agreements atau CCA) yang diperantarai oleh The Nature Conservancy (TNC), yang telah dibawa oleh otoritas taman nasional Indonesia untuk bersama mengelola Taman Nasional Lore Lindu. Hanya wakil To Lindu yang menandatangani perjanjian tersebut pendatang Bugis dan pemukim lain tidak diakui di dalamnya. Pada waktu itu pejabat TNC sendiri mengakui bahwa To Lindu masuk dalam perjanjian tersebut untuk mengedepankan agenda mereka sendiri dalam mendapatkan kembali kendali tanah air mereka. Sebuah laporan TNC mencatat, misalnya, para pemimpin tradisional berusaha untuk mempengaruhi tindakan pendatang baru/imigran ke wilayah tersebut (Acciaioli, 2008b).

Perjanjian konservasi yang dirumuskan di Lindu pada tahun 2001 adalah semacam kantong campuran yang mengandung larangan seperti membuka tanah tanpa persetujuan lembaga adat, memiliki atau menjual tanah tanpa sepengetahuan lembaga adat, dan lainlain. Banyak langkah serupa bisa ditafsirkan sebagai respon terhadap pengalaman pahit alienasi tanah kepada orang Bugis pada tahuntahun sebelumnya. Persetujuan tersebut menegaskan, pada dasarnya, hak To Lindu sebagai penduduk asli dataran dan yang diwakili oleh maradika yang menjadi anggota lembaga adat untuk bertindak sebagai penguasa di domain mereka dan untuk mengelola sumber daya sesuai dengan prioritas mereka sendiri (Li, 2007: 226).

Akibatnya, To Lindu bertindak dalam aliansi dengan pihak konservasi agar lokasi mereka tidak dianggap sebagai frontier kendali, pemukiman, dan ekstraksi - walaupun tindakan dan aliansi itu mengakibatkan penguatan bingkai frontier konservasi. Menerima legitimasi Taman Nasional Lore Lindu sebagai frontier konservasi memungkinkan mereka untuk menggunakan bingkai yang membalikkan eksploitasi Lindu sebagai frontier pemukiman dan ekstraksi oleh para 


\section{Kasus Dataran Lindu Di Sulawesi Tengah}

pendatang. Tetua dari golongan To Lindu yang menjadi anggota lembaga konservasi desa (LKD) yang ditetapkan melalui Kesepakatan Konservasi Masyarakat Dataran Lindu bertindak keras untuk membatasi pembukaan kebun oleh para pendatang baru (misalnya, orang Toraja). Secara eksplisit, mereka melarang pembukaan kebun di daerah batas air (watershed) dan mengukuhkan persyaratan pelaporan bagi para pendatang baru yang berusaha untuk melanjutkan migrasi berantai (Acciaioli, 2008a).

Dalam kapasitasnya sebagai anggota Lembaga Adat Lindu, para tetua bahkan mengeluarkan dekret yang membatasi jumlah lahan yang boleh ditanami oleh seorang individu sejumlah dua hektar, dengan ketentuan semua tanah di luar batas ini akan direklamasi sebagai tanah adat To Lindu. ${ }^{18}$ Meskipun mereka tidak sepenuhnya menutup Lindu sebagai frontier ekstraksi, langkahlangkah tadi telah membatasi ekstraksi oleh pemukim dari luar. Hal itu juga memulai proses golongan To Lindu asli sebagai masyarakat adat dalam usahanya menutup kesenjangan antara kepemilikan lahan mereka dan orangorang migran - dalam istilah Geiger antara pihak "yang diduduki" dan "yang menduduki". Jika Lindu telah menjadi contoh klasik dari daerah "potensi ekonomi untuk eksploitasi manusia ... yang diperebutkan oleh formasi sosial kekuasaan yang tidak setara", seperti yang diungkapkan oleh Geiger (2008a: 77), tindakan To Lindu kini tidak hanya untuk menyamakan kekuatan itu, tetapi juga untuk membalikkan hubungan kekuasaan yang selama ini menempatkan pribumi di bawah pemukim - dalam istilah penulis, mengadakan defrontierisation.

18 Dekrit ini secara tegas ditujukan pada migran, khususnya orang Bugis. Beberapa di antaranya telah membuka kebun hingga seluas 12 hektar untuk
Proses defrontierisation ini kemudian diajukan melalui pemekaran Lindu sebagai kecamatan konservasi baru pada tahun 2007. Sekali lagi To Lindu menggunakan konservasi sebagai alasan yang jelas bagi mereka untuk bertindak di bawah naungan persetujuan dengan TNC. Hal itu dilakukan dengan cara paralelisme dari motto kecamatan konservasi Lindu - "hidup saya, bumi saya" - dengan motto TNC - "melindungi alam, melestarikan hidup". Melalui cara tersebut, para pemimpin To Lindu secara efektif berhasil melembagakan kembali Lindu sebagai ngata, meskipun diformat dalam administrasi modern. "Piagam Lindu", yang memberikan dasar bagi kecamatan baru ini, secara resmi menggabungkan kembali lembaga adat To Lindu - yang dalam kecamatan baru ini diangkat ke status Majelis Adat - sebagai bagian resmi dari pemerintah kecamatan.

Salah satu dokumen yang dikeluarkan sebagai bagian dari deklarasi resmi Kecamatan Lindu adalah buku kodifikasi adat Lindu yang berjudul Kapotia Nulibu Ntotua (Maradika Ngata) Ada NtoLindu. Buku ini khususnya mengutarakan alasan pelestarian sebagai dasar adat Lindu: "Tatanan sosial masyarakat adat Dataran Lindu mengambil bentuk peraturan yang menentukan pelanggaran (Waya) dan sanksi (Sompo) dalam hal pelestarian lingkungan dan pemanfaatan sumber daya alam dan ekosistemnya dalam batas-batas tanah adat dan tanah tempat masyarakat Dataran Lindu memiliki hak pakai (ulayat) dan keteraturan masyarakat" (Propinsi Sulawesi Tengah, 2007). Buku pegangan hukum adat Lindu, sebagai bagian dari alat pemerintah kecamatan baru, dikelola sepenuhnya oleh To Lindu, dan secara resmi digunakan dalam usaha

menanam kopi, kakao dan tanaman mereka lainnya, ditambah tanah sawah yang masih mereka kerjakan. 
memberlakukan kembali cara hidup adat di Lindu. Aturan ini membalikkan status akses terbukanya sebagai frontier pemukiman dan ekstraksi dan menetapkan kembali kebiasaan tanah dan sumber daya alam milik bersama (commons) yang diatur oleh adat To Lindu sendiri. Seluruh proses formalisasi kecamatan konservasi berfungsi untuk membangun kembali Lindu sebagai wilayah yang otonom dan berdaulat dalam beberapa segi. Aturan baru dibuat dengan tujuan untuk menangkal frontierisation Lindu yang telah dipengaruhi oleh proyek pemerintahan kolonial, Orde Lama, dan Orde Baru yang memaksakan bingkai kendali melalui homogenisasi pemerintah dan pembinaan atas pemukiman bebas dan ekstraksi oleh migran yang tidak dapat dikenakan oleh aparat adat yang statusnya dijatuhkan oleh pemerintah nasional. Dengan merumuskan kembali adat mereka sebagai sistem manajemen sumber daya alam dan mengelola kawasan dengan cara-cara resmi sebagai bagian dari proses desentralisasi, To Lindu telah menyusun kembali bingkai frontier konservasi untuk memajukan lembaga mereka sendiri dalam proses defrontierisation di dalam dimensi kendali, pemukiman, dan ekstraksi.

\section{Penutup}

Sepanjang sejarah mereka, To Lindu jelas telah mengalami serbuan dari komunitas lain dan instansi luar. Hal itu merupakan proses yang dinamakan pembentukan frontier dan yang akibatnya menjadikan mereka masyarakat pinggiran. Tulisan ini mencoba memberikan analisis yang lebih artikulatif dengan menelusuri bagaimana berbagai lintasan frontierisation dan defrontierisation dalam aspek kendali, ekstraksi, pemukiman, dan dalam konteks yang lebih kontemporer konservasi, bisa dipasang untuk membentuk sejarah daerah ini sebagai kumpulan proses yang saling bertautan dan berbeda dan yang mengintensifkan dan melemahkan sebuah frontier. Kendali, pemukiman, ekstraksi dan konservasi semua telah menjadi relevan di wilayah Dataran Lindu sebagai bingkai untuk pendirian frontier dan - sampai batas-batas tertentu - juga pembalikan status frontier.

Dengan mengkonseptualisasikan kembali gagasan frontier dalam hal lintasan frontierisation dan defrontierisation ini, penulis telah berusaha untuk memajukan studi hubungan antara pihak yang menduduki dan pihak yang diduduki - atau dengan kata lain pihak yang meminggirkan dan pihak yang dipinggirkan - di daerah-daerah frontier. Meskipun penulis telah mendasarkan analisis ini pada tipologi Geiger tentang frontier kendali, pemukiman, dan ekstraksi, penulis telah menambahkan tipe keempat, yaitu frontier konservasi, yang serupa dengan daerah perbatasan penyelamatan (salvage) seperti yang dijelaskan oleh Tsing. Hal ini perlu dilakukan untuk menjelaskan pembentukan sejenis frontier yang dipengaruhi oleh intervensi dari instansi konservasi, terutama di daerah kawasan lindung seperti taman nasional.

Seperti yang dilakukan oleh kendali, pemukiman, dan ekstraksi, konservasi menetapkan batas-batas baru, menciptakan zona baru, mengubah campuran dari tiga dimensi yang lain tersebut, dan menyusun kembali hubungan antara orang asli dan pendatang. Di abad kedua puluh satu, frontier konservasi akan menjadi semakin penting sebagai implementasi dari program-program seperti pemasaran karbon, termasuk REDD+, dan skema kompensasi lainnya untuk para penjaga hutan lokal, dan sebagai saluran untuk mengubah pola kendali, pemukiman, dan ekstraksi. 


\section{Kasus Dataran Lindu Di Sulawesi Tengah}

Akhirnya, dalam karakterisasi lintasan defrontierisation, penulis agak membedakan analisis ini dari keterangan pembalikan status frontier yang sudah ada. Penulis tidak mengutamakan kriteria pencapaian beberapa ambang kepadatan pemukiman atau indeks yang serupa lainnya, seperti yang telah tercantum di awal argumen tentang pembalikan status frontier di wilayah Barat Amerika Serikat. Sebaliknya, penulis mengutamakan agensi masyarakat lokal dalam upaya mereka untuk membalikkan hubungan asimetris antara pihak yang menduduki (mendominasi) dan pihak yang diduduki (didominasi) sebagai kriterium utama untuk mengidentifikasi proses defrontierisation. Dengan menggunakan kerangka analisis frontierisation dan defrontierisation ini penulis harap tulisan ini berhasil, walaupun tidak selengkapnya, "melakukan analisis tentang proses-proses sosial, politik, ekonomi maupun kebudayaan yang dianggap telah mengakibatkan terjadinya peminggiran sebagian warga bangsa" (Tirtosudarmo, 2017) dan selain itu bagaimana status pinggiran itu bisa diatasi melalui agensi dari masyarakat beraliansi dengan pihak lain, seperti instansi konservasi dan gerakan masyarakat adat.

\section{Daftar Pustaka}

Acciaioli, G. 2009. "Conservation and Community in the Lore Lindu National Park: Customary Custodianship, MultiEthnic Participation, and Resource Entitlement." Dalam C. Warren \& J. McCarthy (Eds.), Community, Environment and Local Governance in Indonesia Locating the Commonweal. Oxon: Routledge, hlm, 88-118.

2008a. "Environmentality Reconsidered:

Indigenous To Lindu Conservation
Strategies and the Reclaiming of the Commons in Central Sulawesi, Indonesia." Dalam M. Galvin \& T. Haller (Eds.), People, Protected Areas and Global Change: Participatory Conservation in Latin America, Africa, Asia, and Europe. Bern: Geographica Bernensia (Perspectives of the Swiss National Centre of Competence in Research (CCR) North-South, University of Bern, Vol. 3.), 401-430.

2008b. "Strategy and Subjectivity in Comanagement of Lore Lindu National Park (Central Sulawesi, Indonesia)". Dalam N. Sodhi, G. Acciaioli, M. Erb \& A.K_J Tan (Eds.), Biodiversity and human livelihoods in Protected Areas: Case Studies from the Malay Archipelago. Cambridge: Cambridge University Press, 266-288.

2001. "Grounds of Conflict, Idioms of Harmony: Custom, Religion, and Nationalism in Violence Avoidance at the Lindu Plain, Central Sulawesi." Indonesia, 72: 81-112.

2000. "Kinship and Debt: The Social Organization of Bugis Migration and Fish Marketing at Lake Lindu, Central Sulawesi." Dalam R. Tol, K. van Dijik \& G. Acciaioli (Eds.), Authority and Enterprise among the Peoples of South Sulawesi. Leiden: KITLV Press (Verhandelingen 188), 210-239.

1999. "Principles and Strategies of Bugis Migration: Some Contextual Factors Relating to Ethnic Conflict." Masyarakat Indonesia: Majalah Ilmu- Ilmu Sosial Indonesia, 25(2): 239-268.

1985. "Culture as Art: From Practice to Spectacle in Indonesia." Canberra Anthropology (Special issue: Minorities and the State), 8(1\&2), 148-172.

Acciaioli, G. \& Sabharwal, A. 2017. "Frontierization and Defontierization: 
Reconceptualizing Frontier Frames.” Dalam J. Moreno \& B. Tatar (Eds.), Transnational Frontiers of Asia and Latin America from 1800. Burlington Oxon: Ashgate - Taylor and Francis, 313-45.

Adriani, N. 1898. "Het Lindu-Meer." Mededeelingen van wege het Nederlandsche Zendelinggenootschap (Tijdschrift voor Zendingswetenschap), 42(1): 107-110.

Adriani, N. \& Kruyt, A.C. 1898. "Van Posso naar Parigi, Sigi en Lindoe." Mededeelingen van wege het Nederlandsch Zendelinggenootschap (Tijdschrift voor Zendingswetenschap), 42(2): 369-535.

Aragon, L. 2000. Fields of the Lord: Animism, Christian Minorities, and State Development in Indonesia. Honolulu: University of Hawaii Press.

Aragon, L. 1996a. "Japanese time' and the mica mine: Experiences of the occupation in the western Central Sulawesi highlands" Journal of Southeast Asian Studies, 27(1): 49-63.

Aragon, L. 1996b. "Twisting the Gift: Translating Precolonial into Colonial Exchanges in Central Sulawesi, Indonesia." American Ethnologist, 23(1): 43-60.

Blower, J.J., Wind, J. \& Amir, H. 1977. "Proposed Lore Kalimantan National Park Management Plan 1978/79-1980/1981.” Directorate of Nature Conservation, Directorate-General of Forestry, Republic of Indonesia in association with the Nature Conservation and Wildlife Management Project of the Food and Agriculture Organization of the United Nations.

Bohannan, P. 1967. "Introduction." Dalam P. Bohannan \& F. Plog (Eds.) Beyond the Frontier: Social Process and Cultural Change. Garden City: The Natural History Press (American Museum Sourcebooks in Anthropology), xi-xviii.
Boonstra van Herdt, R. 1914. "De berglandschappen (Koelawi, Lindoe, Toabakoe, Tolé, Banasu) behoorende tot de onderafdeeling Paloe van Midden Celebes." Tijdschrift van het Koninklijk Nederlandsch Aardrijkskundig Genootschap (seri ke2), 13: 618-644.

Brouwer, M. 1977. 60 tahun Bala Keselematan di Sulawesi Tengah. Bandung: Bala Keselematan.

Caddy, R. 1982. Where the Pepper Grows: The story of Edward Rosenlund. London: Salvationist Publishing and Supplies. Ltd.

Cole, J.W. \& Wolf, E.R. 1974. The Hidden Frontier: Ecology and Ethnicity in an Alpine Valley. New York \& London: Academic Press.

Cribb, R. n.d. [1990]. The Politics of Environmental Protection in Indonesia. Clayton VIC: The Centre of Southeast Asian Studies, Monash University (Working Paper No. 48).

Cribb, R. 2019. "Minorities in Indonesian history: From Ambiguous advantage to cantonisation." Dalam G. Fealy \& R. Ricci (Eds.), Contentious Belonging: The Place of Minorities in Indonesia. Singapore: ISEAS Yusof Ishak Institute, 19-35.

Davis, G. n.d.a [1974]. Parigi: A Social History of the Balinese Movement to Central Sulawesi, 1907-1974. Unpublished PhD thesis, Department of Anthropology, Stanford University.

Davis, G. n.d.b [c.1973]. The People and Legends of Lake Lindu, Central Sulawesi, Indonesia. Naskah yang tidak diterbitkan. Disediakan untuk Museum Negeri Propinsi Sulawesi Tengah, Departemen Pendidikan dan Kebudayaan, Tingkat Propinsi, Palu.

Geiger, D. 2008a. "Turner in the Tropics: The Frontier Concept Revisited." Dalam D. Geiger (Ed), Frontier Encounters: 


\section{Kasus Dataran Lindu Di Sulawesi Tengah}

Indigenous Communities and Settlers in Asia and Latin America. Copenhagen: International Work Group for Indigenous Affairs, Swiss National Centre of Competence in Research North-South (IWGIA Document No. 120), 77-125.

Geiger, D. (Ed). 2008b. Frontier Encounters: Indigenous Communities and Settlers in Asia and Latin America. Copenhagen: International Work Group for Indigenous Affairs, Swiss National Centre of Competence in Research North-South (IWGIA Document No. 120).

Haba, J. n.d. [2001]. Resettlement and Sociocultural Change among the 'Isolated Peoples' in Central Sulawesi, Indonesia: A Study of three Resettlement Sites. Unpublished $\mathrm{PhD}$ thesis, The University of Western Australia.

Hart, C. van der 1853. "Reize Rondom het Eiland Celebes en naar eenige der Moluksche Eilanden gedaan in den jare 1850 door z.M. Schen Van Oorlog Argo en Bromo, onder Bevel van C. van der Hart." 's-Gravenhage: K. Fuhri (vanwege het Koninklijk Instituut voor Taal-, Land- en Volkenkunde van Neerlandsch- Indië).

Hallowell, A.I. 1967. "The Backwash of the Frontier: The Impact of the Indian on American Culture." Dalam P. Bohannan \& F. Plog (Eds,), Beyond the Frontier: Social Process and Cultural Change. Garden City: The Natural History Press (American Museum Sourcebooks in Anthropology), 319-345.

Harvey, B.S. 1977. Permesta: Half a Rebellion. Ithaca NY: Cornell Modern Indonesia Project, Southeast Asia Program, Cornell University. (Monograph Series, Publication No. 57).

Harvey, B.S. n.d. [1974]. Tradition, Islam, and Rebellion: South Sulawesi 1950-1965.
Unpublished $\mathrm{PhD}$ thesis, Department of Government, Cornell University. Ann Arbor: University Microfilms.

Henley, D. 2005. Fertility, Food and Fever: Population, Economy and Environment in North and Central Sulawesi, 1600- 1930. Leiden: KITLV Press (Verhandelikningen van het Koninklijk Instituut voor Taal-, Land- en Volkenkunde 201).

Hvalkof, S. 2008. "Colonization and Conflict on the Amazon Frontier: Dimensions of Interethnic Relations in the Peruvian Montana”. Dalam D. Geiger (Ed), Frontier Encounters: Indigenous Communities and Settlers in Asia and Latin America. Copenhagen: International Work Group for Indigenous Affairs, Swiss National Centre of Competence in Research North-South (IWGIA Document No. 120), 219-286.

Jackson, K.D. 1980. Traditional Authority, Islam, and Rebellion: A Study of Indonesian Political Behavior. Berkeley: University of California Press.

Jones, S. 2019. "Manipulating minorities and majorities: Reflections on 'contentious belonging'." Dalam G. Fealy \& R. Ricci (Eds.), Contentious Belonging: The Place of Minorities in Indonesia. Singapore: ISEAS Yusof Ishak Institute, 255-265.

Jones, T. 2013. Culture, Power, and Authoritarianism in the Indonesian State: Cultural Policy across the Twentieth-Century to the Reform Era. Leiden: Brill.

Kaudern, W. 1925. Migrations of the Toradja in Central Celebes. Goteborg: Elanders Boktryckeri Aktiebolag, 1925. (Jilid 2 Ethnographical Studies in Celebes: Results of the Author's Expedition to Celebes 19171920. 6 jilid, 1925-1944).

Kaudern, W. 1940. The Noble Families or Maradika of Koelawi, Central Celebes. Etnologiska Studier, 11: 30-124. 
Klerck, E.S. de 1938. History of the Netherlands East Indies. 2 jilid. Rotterdam: W. L. \& J. Brusse.

Klinken, G. van 2007. Communal Violence and Democratization in Indonesia: Small town wars. London: Routledge (Routledge Contemporary Southeast Asia Series).

Kruyt, A.C. 1898. "De Opsporing van het Lindoe-Meer op Celebes." Tijdschrift van het Koninklijk Nederlandsch Aardrijkskundig Genootschap, seri ke2, 15(1): 46.

1938. De West-Toradjas op Midden-Celebes. 4 jilid. Amsterdam: De N.V. NoordHollandsche Uitgevers-Maatschappij. (Verhandelingen Der Koninklijke Nederlandsche Akademie van Wetenschappen te Amsterdam, Afdeeling Letterkunde, Nieuwe Reeks 40).

Lattimore, O.D. 1968. "The Frontier in History." Dalam R.A. Manners \& D. Kaplan (Eds.), Theory in Anthropology: A Sourcebook. Chicago: Aldine Publishing (Penerbitan pertama di Relazioni del X Congresso Internazionale di Scienze Storiche (Florence, 1956)).

Li, T.M. 2007. The Will to Improve: Governmentality, Development, and the Practice of Politics. Durham: Duke University Press.

2000. "Articulating Indigenous Identity in Indonesia: Resource Politics and the Tribal Slot." Comparative Studies in Society and History, 42(1): 149-179.

Little, P.E. 2001. Amazonia: Territorial Struggles on Perennial Frontiers. Baltimore and London: The Johns Hopkins University Press.

Mailrapporten 1902 Mailrapporten. Algemeen Rijksarchief (den Haag), Tweede Afdeling- Kolonien.

Mittermeier, R.A., Gil, P.R., Hoffmann, M., Pilgrim, J., Brooks, T., Mittermeier, C.G.,
Lamoreux, J., Fonseca, G.A.B. da. 2004. Hotspots Revisited. Mexico City: CEMEX.

Ostrom, E. 1990. Governing the Commons: The Evolution of Institutions for Collective Action. Cambridge: Cambridge University Press.

Pemberton, J. 1994. On the Subject of 'Java'. Ithaca: Cornell University Press.

Propinsi Sulawesi Tengah, Kabupaten Donggala, Dataran Lindu 2007. Kapotia Nulibu Ntotua (Maradika Ngata) Ada NtoLindu: Hukum Adat Lindu. Enclave Taman National Lore Lindu.

Rowe, W.T. 2007. "Owen Lattimore, Asia, and Comparative History." The Journal of Asian Studies, 66(3): 759-786.

Sangaji, A. 2000. PLTA Lore Lindu: Orang Lindu Menolak Pindah. Yogyakarta: Pustaka Pelajar kerjasama dengan Yayasan Tanah Merdeka, ED Walhi Sulawesi Tengah.

Sangaji, A., Hamdin, M., Sugiharto, Lumeno, F., Lahigi, S. \& Lumeno, F. 2004. Masyarakat dan Taman Nasional Lore Lindu. Jakarta: Yayasan Kemala dan Yayasan Tanah Merdeka.

Sarasin, P. \& Sarasin, F. 1905. Reisen in Celebes: Ausgefuhrt in Den Jahren 18931896 und 1902-1903, 2 jilid. Wiesbaden: C.W. Kreidel's Verlag.

Stevens, A.M. \& Schmidgal-Tellings, A.E. 2004. A Comprehensive IndonesianEnglish Dictionary. Athens OH: Ohio University Press and American Indonesian Chamber of Commerce.

Taman Nasional Lore Lindu 2004. Taman Nasional Lore Lindu: Rencana Pengelolaan (Buku 1: Rencana Pengelolaan). Palu: Balai Taman Nasional Lore Lindu, Direktorat Jenderal Perlindungan Hutan dan Konservasi Alam, The Nature Conservancy. 
Tirtosudarmo, R. n.d. [2017]. Masyarakat Pinggiran dalam Dinamika Kebangsaan dan Agenda Kedepan. Naskah yang tidak diterbitkan (n.d.).

Turner, F.J. 1994. "The significance of the frontier in American history." Dalam J.M. Faragher (Ed), Rereading Frederick Jackson Turner. New York: Henry Holt, 3160.

Tsing, A.L. 2005. Friction: An Ethnography of Global Connection. Princeton: Princeton University Press.

Vlaardingen, A. van 1937. "Het Leger des Heils in Ned. Oost-Indië." Dalam Gulden Schooren van Gods Anker: Gedenkboek ter Gelegenheid van het 50-Jarig Bestaan van het Leger des Heils in Nederland, 18871937. Wageningen: Leger des Heils door Gebr. Zomer en Keunings Uitgeversmaatschappij N.V.

Vorstman, J.A. n.d. "Aanvullende Memorie van Overgave van den Controleur van Paloe.” Memorie van Overgave yang tidak diterbitkan, Algemeen Rijksarchief, Tweede Afdeling - Koloniale Aanwinsten, Memories van Overgave Nederlands-Indië KIT Nr. 690, 28 Februari 1935.

Watling, D, \& Mulyana, Y. 1981. Lore Lindu National Park Management Plan 19811986 (Laporan yang disediakan oleh World Wildlife Fund - Indonesia Programme [Bogor] untuk Directorate of Nature Conservation, Directorate General of Forestry, Republic of Indonesia).

Webb, W.P. 1952. The Great Frontier. Cambridge MA: The Riverside Press.

Whitten, T., Mustafa, M., Henderson, G.S. (2002). The Ecology of Sulawesi, edisi ke2. Singapore: Periplus (The Ecology of Indonesia Series, jilid IV). 
FRONTIERISATION DAN DEFRONTIERISATION 